\title{
Article
}

\section{The Health Impact Fund: How Might It Work for Novel Anticoagulants in Atrial Fibrillation?}

Banerjee, Amitava and Pogge, Thomas W

Available at http://clok.uclan.ac.uk/11760/

Banerjee, Amitava and Pogge, Thomas W (2014) The Health Impact Fund:

How Might It Work for Novel Anticoagulants in Atrial Fibrillation? Global Heart, 9 (2). 255-261.e2. ISSN 22118160

It is advisable to refer to the publisher's version if you intend to cite from the work. http://dx.doi.org/10.1016/j.gheart.2014.01.005

For more information about UCLan's research in this area go to http://www.uclan.ac.uk/researchgroups/ and search for < name of research Group>.

For information about Research generally at UCLan please go to http://www.uclan.ac.uk/research/

All outputs in CLoK are protected by Intellectual Property Rights law, including Copyright law. Copyright, IPR and Moral Rights for the works on this site are retained by the individual authors and/or other copyright owners. Terms and conditions for use of this material are defined in the policies page. 
The Health Impact Fund:How might it work for novel anticoagulants in atrial fibrillation?

Amitava Banerjee MA MPH DPhil ${ }^{1}$

Thomas Pogge PhD ${ }^{2}$

${ }^{1}$ Centre for Cardiovascular Sciences, University of Birmingham, UK

2 Department of Philosophy, Yale University, USA

Corresponding author

Dr Amitava Banerjee

University of Birmingham Centre for Cardiovascular Sciences

College of Medical\&Dental Sciences, School of Clinical and Experimental Medicine Edgbaston, Birmingham

West Midlands , UK

B15 2TT

E-mail: a.banerjee.1@bham.ac.uk

Telephone: 07779101608 Fax: 01215544083

Word count (excluding abstract, but including references) $=4780$ words

\section{Funding:}

The research leading to these results has received funding from the European Research Council under the European Union's Seventh Framework Programme (FP/2007-2013)/ERC Grant Agreement no. 339239. 


\begin{abstract}
Background

Cardiovascular diseases represent the greatest burden of global disease. Spending on cardiovascular diseases is higher than for other diseases, with the majority being spent on drugs. Therefore, these drugs and these diseases are hugely important to health systems, society and pharmaceutical companies. The Health Impact Fund represents a new mechanism by which pharmaceutical innovators would be rewarded on the basis of health impact of their new drugs.
\end{abstract}

\title{
Objective
}

To illustrate the concept of the Health Impact Fund using the example of novel anticoagulants for prevention of stroke and thromboembolism in atrial fibrillation.

\section{Discussion}

By considering existing data and the current situation for novel anticoagulants, we suggest that epidemiologic data and modelling techniques can be used to predict future trends in disease and the health impact of new drugs.

\section{Conclusion}

The Health Impact Fund may offer potential benefits to pharmaceutical companies, patients and governments and warrants proper investigation.

Keywords: access to medicines, pharmaceutical, equity, epidemiology 


\section{Abbreviations}

CVD: Cardiovascular disease

HIF: Health Impact Fund

LIMC: Low-Middle Income Country

AF: Atrial fibrillation

NOAC: Novel anticoagulant

GBD: Global Burden of Disease 
Objective To describe the Health Impact Fund, using the example of novel anticoagulants for prevention of stroke and thromboembolism in atrial fibrillation.

\section{Introduction}

Burden of disease due to cardiovascular disease(CVD) is greater than for any other disease globally ${ }^{1-3}$. CVDs are firmly on the global health policy agenda ${ }^{4-6}$. Spending on CVD is greater than for any other disease globally, e.g.hypertension represents over $10 \%$ of healthcare expenditure globally ${ }^{7,8}$. Inter-sectoral and inter-disciplinary approaches are essential to reduce global $C V D^{4,9}$.

Most healthcare spending (as in CVD), particularly in low- and middle-income countries(LMICs) and particularly out-of-pocket expenditure, is on drugs ${ }^{10-12}$. Every stage of CVD(primary prevention, secondary prevention and acutely) requires drugs. Efforts to reduce global healthcare costs must involve drugs used to prevent or treat CVD.

Drugs to treat CVD and its risk factors have topped blockbuster charts for over 30 years, whether anti-clotting drugs(e.g.clopidogrel; Plavix ${ }^{\mathrm{TM}}$ ), statins(e.g.simvastatin, Zocor $^{\mathrm{TM}}$ ) or anti-hypertensives(e.g.lisinopril, Carace $\left.{ }^{\mathrm{TM}}\right)^{13-14}$. Some of the largest cases of misconduct in trials have occurred in CVDs(e.g.rofecoxib,Vioxx $\left.{ }^{\mathrm{TM}}\right)^{15}$. These drugs and diseases are important to health systems, society and pharmaceutical companies and improved drug access may produce the greatest gains.

In this review, implications of intellectual property rights on access to medicines and innovation are examined. Potential solutions are explored. We will define the Health Impact Fund(HIF), a novel proposal to incentivise development and distribution of drugs depending on global health impact. The potential role of the HIF will be considered with respect to novel anticoagulants(NOACs) for stroke prevention in atrial fibrillation(AF).

\section{Intellectual property rights}

Until 1994, intellectual property rights were enforced strictly in wealthy countries, whereas LMICs had much weaker patent laws, if any. . Since 1994, LMICs agreed to institute TRIPS(Trade-Related Aspects of Intellectual Property Rights)-compliant 
systems ${ }^{16}$. TRIPS became more constraining as increased numbers of countries implement patent exclusivity, shaping all intellectual property rights, including drugs. Although TRIPS implementation and affordability are not the only factors contributing to access, TRIPS has probably widened global health inequalities ${ }^{17-19}$ (figure 1).

New technologies, including drugs, have been "produced by companies from highincome countries for high-income markets" 20,21 . The industries and the incentives are not aligned with access, which acts as both determinant and consequence of inequalities in health, income and development ${ }^{17,19}$. Access to drugs is one of global health's greatest challenges. Even for cheap, generic drugs with proven efficacy, rates of use and access are suboptimal. A recent study of global secondary CVD prevention showed that few individuals took antiplatelet drugs(25.3\%), beta-blockers(17.4\%), angiotensin converting enzyme-inhibitors(ACEIs), ARBs(angiotensin 2-receptor blockers)(19.5\%), or statins(14.6\%) ${ }^{22}$. These data suggest that health system improvements are needed to affect drug access. New CVD drugs may not have a major effect when established drugs are so under-used. However, in certain instances, new drugs have transformed disease management(e.g. statins in CVD prevention or ACEIs for hypertension). Intellectual property rights can directly influence affordability,sustainability and rational selection by practitioners by highlighting new drugs with greatest health impact. Indirectly,pharmaceutical companies may be incentivised to improve infrastructure and proper use by health professionals and individuals(figure 1). Therefore, intellectual property rights and new drugs may have wide implications on global health impact.

Ethical and human rights arguments have been used for access to healthcare ${ }^{4,23,24}$, which should guide governments and industries to produce accessible medicines. However, access is not simply based on cost and affordability. If other factors are neglected, benefits of available drugs will not be realised. Even if appropriate, essential medications are available, their correct use is not guaranteed ${ }^{17,19}$. Governments, pharmaceutical companies, society and individuals all have a role to play. However, responsibility for providing access to drugs is in the hands of the stakeholders with greatest capability, namely pharmaceutical companies and governments ${ }^{19}$. Cost of drugs represents a unique opportunity to change the current paradigm(figure 1). 


\section{Current solutions}

Where cost of medications restricts their provision, several potential solutions have been utilised. First, generic drugs are cheaper than branded versions. Indian companies supply low-cost generics(including CVD drugs), domestically, to other LMICs and increasingly to wealthier countries as well. If generics are used to substitute branded drugs, especially in CVD, economic and public health benefits are likely ${ }^{25}$. Until 2005, India could avoid introducing product patents, although process patents were already available prior to TRIPS ${ }^{26,27}$. However, a recent analysis of new patents filed in India since 2005 suggests no relationship with disease burden or public health priorities $^{28}$.

Second, charitable donations from wealthy countries and pharmaceutical companies are possible. . Since treatments for CVD) are often long-term, if not lifelong, a more sustainable supply is needed.

Proponents of TRIPS state that it contains provisions which allow prioritisation of public health needs. Parallel imports are imports of a patented or trademarked product from a country where it is already marketed ${ }^{29}$. Compulsory licensing is when a government allows someone else to produce the patented product or process without the consent of the patent owner ${ }^{30}$. However, LMICs have not adequately used existing provisions with public health consequences ${ }^{31}$. In summary, CVD drugs are neither available nor affordable in many countries, particularly in the public sector 32.

\section{The Health Impact Fund}

There are no incentives for pharmaceutical companies to develop, market or deliver drugs which will have maximal impact on global health. Such mechanisms would make greatest difference in CVDs, which represent largest disease burden, highest drug spending and greatest number of new drugs in recent years.

The Health Impact Fund (HIF) would reward pharmaceutical companies in proportion to global health impact of their innovation ${ }^{17}$. As a global agency underwritten by governments, it would offer pharmaceutical companies the option to register new 
products. Registration would entitle innovators to receive, for a defined period(e.g.10 years), a share of fixed renumeration from a reward pool. The fund would disburse at least US\$6 billion annually, paying each registrant a share corresponding to contribution to global health impact of all registered drugs, as estimated with a global health impact assessment exercise(web appendix 1). In return, the registrant would sell the medicine wherever needed at no more than the lowest feasible cost of production and distribution. After the reward period, free licences would enable generic manufacture and sales ${ }^{17}$.

The HIF has gained momentum ${ }^{33,34}$, but the next challenges are finding PCs willing to license their novel products and credible methodology for health impact assessment to test the HIF.

\section{New drugs and new trials}

Atrial fibrillation (AF) is the commonest arrhythmia and is a major cause of stroke and thromboembolism ${ }^{35}$. NOACs are an alternative to warfarin, the mainstay of anticoagulation for over 50 years ${ }^{36-37}$. In the last 3 years, following successful phase 3 clinical trials, three agents(dabigatran, apixaban and rivaroxaban) have been incorporated into guidelines worldwide and more NOACs are in the pipeline ${ }^{38-40}$. As with statins, ACEIs, ARBs and other CVD drug classes, "me-too" agents are anticipated and trials are already underway ${ }^{41-44}$. "Me-too" drugs are expensive and do not serve society well ${ }^{41-43}$. The HIF may combine profits with patient benefit in a mutually beneficial manner.

Imagine that the pharmaceutical companiesproducing NOACs registered with the HIF. Based on trials or predicted trial outcomes (for edoxaban ${ }^{44}$ ), the reward for each NOAC would be estimated. Most NOACs have been subject to trials in deep-vein thrombosis(DVT) prior to trials in AF. Potential impact of NOACs could be estimated based on DVT trials if AF trials were not yet completed.

Subgroup analyses are often reported in trials to quantify drug effects in different subpopulations. Ideally, subgroups should be defined before trial initiation, but posthoc analyses are often reported. Although post-hoc analyses have possible biases 
and limitations, they may be useful for modelling. Possible subgroups for NOACs include age, renal function or other cardiovascular risk factors ${ }^{38-40,45-46}$.

NOACs, like warfarin, and all drugs, have risks(excess bleeding) as well as benefits (prevention of stroke/thromboembolism). Trial data may be used to estimate risks as well as benefits, and to compare different agents. Health impact assessment will aim to model incremental benefit of new drugs versus current "gold-standard" therapy or other new drugs. For anticoagulants, "net clinical benefit" balances risk of bleeding versus benefit of stroke prevention ${ }^{47}$ and and has been used to compare NOACs and warfarin $^{48-49}$. Similar concepts could be used for health impact assessment of other new drugs.

\section{Identifying datasets}

National and local datasets offer invaluable resources from which the target population can be modelled, e.g. the UK's Clinical Practice Research Datalink ${ }^{50}$ and the Danish national healthcare database ${ }^{48}$. Regional variations occur in distribution of risk factors and disease ${ }^{51}$. The more accurately these variations can be incorporated into models, the better the estimation of drug effects. The Global Burden of Disease(GBD) Study has revolutionised knowledge of prevalence, time trends and predictions for disease and risk factors ${ }^{52,53}$. GBD data could be used to model patient populations and drug effects at country level. However, there is variation in missing data and methodologies of data collection across countries; e.g.there is incomplete death registration in many LMICs; with some having no death registration data at all54-55.

Registries can be local, regional, national or multi-national56. AF registries have highlighted risk associations ${ }^{57}$ and have been used to model effects of population-wide implementation of NOACs ${ }^{58}$ and differences between "real-world" and "clinical trial" effects $^{59}$. Global registries can be powerful in learning about current risk factor and disease trends, and clinical practice ${ }^{60-61}$. However, registries also have limitations, including variable data selection and data quality due to varying methodologies ${ }^{62}$.

Tools are increasingly used to predict risk of disease outcomes in different populations. In AF, several risk prediction tools for stroke/thromboembolism and bleeding are validated, widely used ${ }^{63-66}$, and have been used to define subgroups 
within studies ${ }^{49}$. In individuals, these tools allow trial results to be personalised; e.g.stroke/thromboembolism risk associated with each level of $\mathrm{CHA}_{2} \mathrm{DS}_{2}-\mathrm{VASc}$ score has been investigated in multiple studies. If the $\mathrm{CHA}_{2} \mathrm{DS}_{2}-\mathrm{VASc}$ distribution can be estimated in a population, the drug effects at each level of $\mathrm{CHA}_{2} \mathrm{DS}_{2}-\mathrm{VASc}$ may be modelled, for the health impact assessment.

Optimal data sources will be identified for a particular context(preferably at multiple levels,i.e. local, regional, national) ${ }^{67}$. Growing transparency and public availability of data from trials will benefit the HIF68-69.

\section{Modelling}

Analyses of population impact, potential cost and comparative analysis of NOACs would be required. The population attributable risk is the proportion of a given disease which can be attributed to a specific risk factor(e.g. AF), whether clinical0 ${ }^{70}$ or subclinical ${ }^{71}$ and may be useful for estimating burden of $\mathrm{AF}$ and stroke/ thromboembolism. The "potentially modifiable burden" of disease (e.g. stroke) may be useful in describing potential benefits of drugs ${ }^{72}$.

The IMPACT model shows how evidence can inform public health policy ${ }^{73,74}$. The "policy effectiveness-feasibility loop" involves:(a)epidemiological modelling; (b)situation analysis; and (c)option appraisal ${ }^{74}$. The first stage can be adapted to include modelling of effects of new drugs so that this same framework can be applied to health impact assessment. The IMPACT model has been used to estimate proportion of change in rates of disease which can be attributed to changes in a particular risk factor ${ }^{75-76}$. The IMPACT model has largely been restricted to CHD, but could be used in other diseases.

Projections of AF burden and representativeness of trial populations for NOACs have been studied ${ }^{50,76}$. Trial data can be used to model different levels of prescription, adherence, cost and other environmental factors. Cost-effectiveness analyses are another data source, ${ }^{77,78}$. subject to quality of cost and efficacy data. Incremental costeffectiveness data are of greatest relevance and value to the HIF but often ignored in favour of "cost-effectiveness thresholds"79-80. As with all modelling, limitations and ranges of data must be acknowledged transparently.Different scenarios may be 
constructed within models to simulate impact of several competing drugs, e.g.(a) competing drugs have sustained and equal sales;(b)one of the drugs overtakes its competitors; (c) none of the drugs are taken up to an appreciable extent. Several factors such as adherence, side effects of new drugs, indications included in the drug license and ongoing data collection will be considered as the optimal method of health impact assessment is finalised. "Scenario planning" begins by identifying focal issues or decisions(e.g.effect of introduction of a NOAC on use of warfarin, use of NOACs, access to drugs and rates of stroke/thromboembolism) and predicts future environment ${ }^{81-84}$. Four factors shape future scenarios ${ }^{83}$.

\section{Social}

Social factors, include: increasing burden of AF and stroke due to ageing populations and demographic transition, values systems(e.g.more demand for equity and corporate social responsibility), lifestyle(e.g.adherence), demand(increasing demand for NOACs from providers and patients), and political energy (to enforce uptake of new drugs).

\section{Economic}

Macroeconomic (e.g. "How will international trade flow and exchange rates affect the price of drugs?"; "How will global pharmaceutical companies respond to pharmaceutical companies from LMICs?") and microeconomic factors(e.g."How much appetite is there in the system for increased spending on new drugs?"; What financial protections protect patients from catastrophic out-of-pocket expenditures on drugs?; "How might the structure of pharmaceutical companies change?"; "How much partnership will exist between different producers of NOACs?") influence uptake and effect of new drugs.

\section{Political}

Local(e.g.interpretation of practice guidelines and evidence), regional(e.g.competition between practice in other centres; competition between existing anticoagulation services and new infrastructure for NOACs), national(e.g.implementation of NICE guidelines) and international(e.g.implementation of TRIPS) environments can affect uptake and effectiveness of new drugs. Across all spheres, level of funding within the health sector and for drugs specifically must be considered 85,86 . 


\section{Technological}

Direct evidence for effectiveness obviously influences how new drugs are incorporated into clinical practice and health systems. Evidence can change over time, relating to "real-world" effects, side-effects and new clinical indications: e.g.NOACs have proven effectiveness in treatment of $\mathrm{DVT}^{87}$. Indirect evidence includes data regarding other competing drugs, new and old. As "me-too" NOACs emerge, their effectiveness and cost-effectiveness may affect and limit uptake and impact of first-generation NOACs. Web appendix 2 highlights an example of scenario modelling.

\section{Reward mechanism}

Health impact assessment should be based on as much high-quality evidence as possible and available. Although models have imperfections and assumptions, any measure of population-based impact will improve on the current paradigm. At present, pharmaceutical company marketing strategies focus on trial data. Health impact assessment requires a longer-term view from both pharmaceutical companies and policymakers. It would be expensive, given the need to assess multiple medicines globally. However, there would also be economies of scale from assessing many medicines at the same time, and efficiencies from assessing the same medicine year after year.

In consultation with stakeholders(including pharmaceutical companies), a reward for a specific health impact threshold will be agreed. If this target is met, then pharmaceutical companies will receive this agreed reward. Health impact assessment by independent assessors would occur annually to estimate actual impact of new drugs and to determine rewards due to pharmaceutical companies. The HIF rewards any company that produces an effective new drug in proportion to how well the drug works, provided that the innovator agrees to sell it at cost price. After the 10-year reward period, the company would also offer free licences to enable generic manufacture and sales. Pharmaceutical companies may be rewarded based on early results and longer-term results may later emerge, showing less benefit or potentially harms associated with the drug. The HIF reward allocated to a drug will be evaluated annually on available evidence and can be changed. Therefore, if a drug actually causes harm, it will not be rewarded. A PC will only receive full reward if the agreed target of impact is met. A consequence of using life-years or disability- or quality- 
adjusted life years as the primary health impact assessment modelling outcome may be that highly effective treatments for rare diseases occurring early in life will have a health impact reward similar to a moderately effective treatment for a common disease occurring in adulthood.

Box 1 summarises potential benefits of the HIF for pharmaceutical companies, patients and governments.

\section{Conclusions}

The current intellectual property rights regime and the way in which novel drugs are evaluated after proof-of-efficacy in trials are inadequate. The HIF offers an alternative mechanism by which pharmaceutical companies could be rewarded based on global health impact of their novel drugs. Using the example of NOACs for stroke prevention in AF, feasible methods of health impact assessment have been suggested. The same principles apply to other current examples, including antiplatelet agents postSTEMI 89,90 . Trials, registries and other datasets offer potential for modelling future trends in disease burden as well as impact of novel drugs.

Judicious use of available data and scenario modelling represent a significant improvement compared with the status quo where rewards have no association with "real-world" impact of drugs. Feasibility of prospective health impact assessment of novel drugs must now be properly tested using different drugs in different disease areas, in order to take forward the concept of the HIF. There is a growing movement to increase the transparency of pharmaceutical companies and to improve access to their drugs ${ }^{91}$. The HIF may be the most sustainable and feasible solution. 


\section{References}

1. Sanderson JE,Mayosi B,Yusuf S,Reddy S,Hu S,Chen Z,Timmis A.Global burden of cardiovascular disease.Heart.2007;93:1175.

2. Levenson JW,Skerrett PJ,Gaziano JM.Reducing the global burden of cardiovascular disease: the role of risk factors.Prev Cardiol.2002;5:188-99.

3. World Health Organization.The Global Burden of Disease:2004 Update. World Health Organization, Geneva, Switzerland (2008)

4. Beaglehole R,Ebrahim S,Reddy KS,Voute J,Leeder S.Prevention of chronic diseases: a call to action.Lancet.2007;370:2152-2157.

5. Daar AS,Singer PA,Persad DL,Pramming SK,Matthews DR,Beaglehole R,Bernstein A,Borysiewicz LK,Colagiuri S,Ganguly N,Glass RI,Finegood DT,Koplan J,Nabel EG,Sarna G,Sarrafzadegan N,Smith R, Yach D,Bell J.Grand challenges in chronic non-communicable diseases. Nature. 2007;450:494-6.

6. Beaglehole R,Bonita R,Alleyne G,Horton R,Li L,Lincoln P,Mbanya JC,McKee M,Moodie R,Nishtar S,Piot P,Reddy KS,Stuckler D; Lancet NCD Action 
Group.UN High-Level Meeting on Non-Communicable Diseases:addressing four questions.Lancet.2011;378:449-55.

7. Gaziano TA,Bitton A,Anand S,Weinstein MC; International Society of Hypertension.The global cost of nonoptimal blood pressure.J Hypertens. 2009;27:1472-7.

8. Garg CC,Evans DB.What is the impact of noncommunicable diseases on National Health Expenditures:A synthesis of available data.Discussion Paper No 3.World Health Organisation, Geneva 2011.

9. Fuster V,Kelly BB,Vedanthan R.Global cardiovascular health:urgent need for an intersectoral approach.J Am Coll Cardiol.2011;58:1208-10.

10. WHO.The world drug situation.Geneva:World Health Organization,1988.

11.WHO.Chronic Diseases Report 2005.Chapter 2:chronic diseases and poverty.Geneva:World Health Organization,2005.

12. Huffman MD,Rao KD,Pichon-Riviere A,Zhao D, Harikrishnan S,Ramaiya K,Ajay VS,Goenka S,Calcagno JI,Caporale JE,Niu S,Li Y,Liu J,Thankappan KR,Daivadanam M,van Esch J,Murphy A,Moran AE,Gaziano TA,Suhrcke M, Reddy KS,Leeder S,Prabhakaran D.A cross-sectional study of the microeconomic impact of cardiovascular disease hospitalization in four lowand middle-income countries.PLoS One.2011;6:e20821.

13. Munos B.Lessons from 60 years of pharmaceutical innovation.Nat Rev Drug Discov.2009;8:959-68.

14. Ma P,Zemmel R.Value of novelty?Nat Rev Drug Discov.2002;1:571-2.

15. Faunce T,Townsend R,McEwan A.The Vioxx pharmaceutical scandal: Peterson v Mercke Sharpe \& Dohme(Aust) Pty Ltd. J Law Med. 2010;18:38-49.

16. Trade-related aspects of intellectual property rights agreement. World Trade Organization. $\quad$ http://www.wto.org/English/tratop e/TRIPS e/trips e.htm (accessed 29/10/2013)

17. Banerjee A,Hollis A,Pogge T.The Health Impact Fund:incentives for improving access to medicines.Lancet.2010;375:166-9.

18. Quick J.D.Ensuring access to essential medicines in the developing countries: A framework for action.Clin Pharm Ther 2003.73:279-283.

19. Banerjee A.Whose responsibility is access to essential drugs for chronic diseases?Ethics and Economics.2006;4:2.

20. Howitt P,Darzi A,Yang GZ,Ashrafian H,Atun R,Barlow J,Blakemore A,Bull AM,Car J,Conteh L,Cooke GS,Ford N,Gregson SA,Kerr K,King D,Kulendran M,Malkin RA,Majeed A,Matlin S,Merrifield R,Penfold HA, Reid SD,Smith PC,Stevens MM,Templeton MR,Vincent C,Wilson E.Technologies for global health.Lancet.2012;380:507-35.

21. WHO.Medical devices: managing the mismatch: an outcome of the priority medical devices project.World Health Organization,Geneva (2010)

22. Yusuf S,Islam S,Chow CK,Rangarajan S,Dagenais G,Diaz R,Gupta R,Kelishadi R, Iqbal R,Avezum A,Kruger A,Kutty R,Lanas F, Lisheng L,Wei L,Lopez-Jaramillo P,Oguz A,Rahman O,Swidan $H$,Yusoff $K$,Zatonski W,Rosengren A,Teo KK;Prospective Urban Rural Epidemiology(PURE) Study Investigators. Use of secondary prevention drugs for cardiovascular disease in the community in high-income, middle-income, and low-income countries(the PURE Study): a prospective epidemiological survey.Lancet.2011;378:1231-43.

23. Follath F.Ethical considerations in cardiovascular prevention.Fundam Clin Pharmacol.2009;23:669-73. 
24. Pulvirenti M,McMillan J,Lawn S.Empowerment, patient centred care and selfmanagement. Health Expect. 2012 Jan 2.[Epub ahead of print]

25.Cameron A,Mantel-Teeuwisse AK,Leufkens HG,Laing RO.Switching from originator brand medicines to generic equivalents in selected developing countries:how much could be saved?Value Health.2012;15:664-73.

26. Sampat BN,Shadlen KC,Amin TM.Intellectual property.Challenges to India's pharmaceutical patent laws.Science.2012;337:414-5.

27. Mosnzynski P.Legal challenge to India's patent laws threatens access to generic drugs, says charity.BMJ 2011;343:d5753.

28. Gupta I,Guin P,Trivedi M.The new patent regime and disease priorities in India.Glob Public Health.2012 Jul 30.

29. Trade, foreign policy, diplomacy and health.World Health Organization. http://www.who.int/trade/glossary/story070/en/ (Accessed 12/12/2013)

30. TRIPS and Health: Frequently asked questions. Compulsory licensing of pharmaceuticals and TRIPS. World Trade Organization.

http://www.wto.org/english/tratop e/trips e/public health faq e.htm (Accessed 12/12/2013)

31. Oliveira MA,Bermudez JA,Chaves GC, Velásquez G. Has the implementation of the TRIPS Agreement in Latin America and the Caribbean produced intellectual property legislation that favours public health?Bull World Health Organ.2004;82:815-21

32.van Mourik MS,Cameron A,Ewen M,Laing RO.Availability,price and affordability of cardiovascular medicines:a comparison across 36 countries using WHO/HAI data.BMC Cardiovasc Disord.2010;10:25.

33. Hollis A and Pogge T.The Health Impact Fund. Making New Medicines Accessible for All.A Report of Incentives for Global Health.Incentives for Global Health 2008. http://machif.com/wpcontent/uploads/2012/11/hif book.pdf (Accessed 12/12/2013)

34. Pogge $T$, Hollis A,Singer $P$,Nathan $C$,Banerjee A,Van Puymbroeck RV, Grootendorst P. The Health Impact Fund: Pay-for-Performance. Submission to WHO Expert Group for Public Health, Innovation and Intellectual Property. April 2009.

35. Ball J,Carrington MJ,McMurray JJ,Stewart S.Atrial fibrillation:Profile and burden of an evolving epidemic in the 21st century.Int $\mathrm{J}$ Cardiol. 2013;167:1807-24.

36. Banerjee A,Marín F,Lip GY.A new landscape for stroke prevention in atrial fibrillation:focus on new anticoagulants, antiarrhythmic drugs, and devices. Stroke.2011;42:3316-22.

37. Schirmer SH,Baumhäkel M,Neuberger HR,Hohnloser SH,van Gelder IC,Lip GY,Böhm M.Novel anticoagulants for stroke prevention in atrial fibrillation: current clinical evidence and future developments.J Am Coll Cardiol. 2010;56:2067-76.

38. Connolly SJ,Ezekowitz MD,Yusuf S,Eikelboom J,Oldgren J,Parekh A,Pogue J,Reilly PA,Themeles E,Varrone J,Wang S,Alings M,Xavier D,Zhu J,Diaz R, Lewis BS,Darius H,Diener HC,Joyner CD,Wallentin L;RE-LY Steering Committee and Investigators.Dabigatran versus warfarin in patients with atrial fibrillation.N Engl J Med. 2009;361:1139-51.

39. Patel MR,Mahaffey KW,Garg J,Pan G,Singer DE,Hacke W,Breithardt G,Halperin JL,Hankey GJ,Piccini JP,Becker RC,Nessel CC,Paolini 
JF,Berkowitz SD,Fox KA,Califf RM;ROCKET AF Investigators.Rivaroxaban versus warfarin in nonvalvular atrial fibrillation. N Engl J Med.2011;365:883-91.

40. Granger CB,Alexander JH,McMurray JJ,Lopes RD,Hylek EM,Hanna M,AlKhalidi HR,Ansell J,Atar D,Avezum A,Bahit MC,Diaz R,Easton JD,Ezekowitz JA,Flaker G,Garcia D,Geraldes M,Gersh BJ,Golitsyn S,Goto S,Hermosillo AG,Hohnloser SH,Horowitz J,Mohan P,Jansky P, Lewis BS, Lopez-Sendon JL, Pais P,Parkhomenko A,Verheugt FW,Zhu J,Wallentin L;ARISTOTLE Committees and Investigators.Apixaban versus warfarin in patients with atrial fibrillation.N Engl J Med. 2011;365:981-92.

41. Gagne JJ,Choudhry NK.How many "me-too" drugs is too many?JAMA.2011;305:711-2.

42. Régnier S.What is the value of 'me-too' drugs? Health Care Manag Sci.2013 Feb 26. [Epub ahead of print]

43. Grabner M,Johnson W,Abdulhalim AM,Kuznik A,Mullins CD.The value of atorvastatin over the product life cycle in the United States. Clin Ther. 2011;33:1433-43.

44. Tahir F, Riaz H,Riaz T,Badshah MB,Riaz IB,Hamza A,Mohiuddin H.The new oral anti-coagulants and the phase 3 clinical trials-a systematic review of the literature.Thromb J.2013;11:18.

45. Hess CN,Al-Khatib SM,Granger CB,Lopes R.A review of apixaban for stroke prevention in atrial fibrillation: insights from ARISTOTLE.Expert Review of Cardiovascular Therapy.2013.11;9:1105-1114.

46. Potpara TS,Polovina MM,Licina MM,Stojanovic RM,Prostran MS,Lip GY. Novel oral anticoagulants for stroke prevention in atrial fibrillation:focus on apixaban.Adv Ther.2012;29:491-507.

47. Singer DE,Chang Y,Fang MC,Borowsky LH,Pomernacki NK,Udaltsova N,Go AS.The net clinical benefit of warfarin anticoagulation in atrial fibrillation.Ann Intern Med 2009;151:297-305.

48. Olesen JB,Lip GY,Lindhardsen J,Lane DA,Ahlehoff O,Hansen ML,Rauns $\varnothing$ J,Tolstrup JS,Hansen PR,Gislason GH,Torp-Pedersen C.Risks of thromboembolism and bleeding with thromboprophylaxis in patients with atrial fibrillation: A net clinical benefit analysis using a 'real world' nationwide cohort study. Thromb Haemost. 2011;106.

49. Banerjee A,Lane DA,Torp-Pedersen C,Lip GY.Net clinical benefit of new oral anticoagulants(dabigatran, rivaroxaban, apixaban) versus no treatment in a 'real world' atrial fibrillation population: a modelling analysis based on a nationwide cohort study. Thromb Haemost.2012;107:584-9.

50. Lee S,Monz BU,Clemens A,Brueckmann M,Lip GY.Representativeness of the dabigatran,apixaban and rivaroxaban clinical trial populations to real-world atrial fibrillation patients in the United Kingdom:a cross-sectional analysis using the General Practice Research Database.BMJ Open. 2012;2(6).

51. Gupta R,Guptha S,Sharma KK,Gupta A,Deedwania P.Regional variations in cardiovascular risk factors in India: India heart watch.World J Cardiol. 2012;4:112-20.

52. Wang $\mathrm{H}$,Dwyer-Lindgren L,Lofgren $\mathrm{KT}$, Rajaratnam JK,Marcus JR, Levin-Rector A,Levitz CE,Lopez AD,Murray CJ.Age-specific and sex-specific mortality in 187 countries,1970-2010:a systematic analysis for the Global Burden of Disease Study 2010.Lancet. 2012;380:2071-94.

53. Ezzati M,Hoorn SV,Lopez AD,Danaei G,Rodgers A,Mathers CD,Murray CJL. Comparative Quantification of Mortality and Burden of Disease Attributable to 
Selected Risk Factors. In: Lopez AD, Mathers CD,Ezzati M,Jamison DT, Murray CJL, editors. Global Burden of Disease and Risk Factors.Washington (DC):World Bank; 2006.Chapter 4.

54. Naghavi M,Makela S,Foreman K,O'Brien J,Pourmalek F,Lozano R.Algorithms for enhancing public health utility of national causes-of-death data. Popul Health Metr 2010,8:9.

55. Polinder S,Haagsma JA,Stein C,Havelaar AH.Systematic review of general burden of disease studies using disability-adjusted life years.Popul Health Metr.2012;10:21.

56. Karthikeyan G,Zühlke L,Engel M,Rangarajan S,Yusuf S,Teo K,Mayosi BM.Rationale and design of a Global Rheumatic Heart Disease Registry:the REMEDY study.Am Heart J.2012;163:535-40.e1.

57. Rivero-Ayerza $M$,Scholte Op Reimer $W$, Lenzen $M$,Theuns DA,Jordaens L,Komajda M,Follath F,Swedberg K,Cleland JG.New-onset atrial fibrillation is an independent predictor of in-hospital mortality in hospitalized heart failure patients: results of the EuroHeart Failure Survey.Eur Heart J.2008;29:1618-24

58. Pisters R,Nieuwlaat R,Lane DA,Crijns HJ,Lip GY.Potential net clinical benefit of population-wide implementation of apixaban and dabigatran among European patients with atrial fibrillation.A modelling analysis from the Euro Heart Survey.Thromb Haemost. 2013;109:328-36.

59. Pfeilschifter W,Luger S,Brunkhorst R,Lindhoff-Last E,Foerch C.The Gap between Trial Data and Clinical Practice-An Analysis of Case Reports on Bleeding Complications Occurring under Dabigatran and Rivaroxaban Anticoagulation.Cerebrovasc Dis.2013;36:115-119.

60. Kakkar AK,Mueller I,Bassand JP,Fitzmaurice DA,Goldhaber SZ, Goto S, Haas S,Hacke W,Lip GY,Mantovani LG,Turpie AG,van Eickels M,Misselwitz F,Rushton-Smith S,Kayani G,Wilkinson P,Verheugt FW;GARFIELD Registry Investigators.Risk profiles and antithrombotic treatment of patients newly diagnosed with atrial fibrillation at risk of stroke:perspectives from the international, observational, prospective GARFIELD registry.PLoS One.2013;8:e63479.

61. Apenteng PN,Murray ET,Holder R,Hobbs FD,Fitzmaurice DA;UK GARFIELD Investigators and GARFIELD Steering Committee.An international longitudinal registry of patients with atrial fibrillation at risk of stroke (GARFIELD):the UK protocol.BMC Cardiovasc Disord.2013;13:31.

62. Sorenson HT.Regional administrative health registries as a resource in clinical epidemiology.A study of options, strengths, limitations and data quality provided with examples of use.Int J Risk Saf Med.1997;10:1-22.

63. Gage BF,Waterman AD,Shannon W,Boechler M,Rich MW, Radford MJ.Validation of clinical classification schemes for predicting stroke: results from the National Registry of Atrial Fibrillation.JAMA 2001;285:2864-2870.

64. Lip GY,Nieuwlaat R,Pisters R,Lane DA,Crijns HJ.Refining clinical risk stratification for predicting stroke and thromboembolism in atrial fibrillation using a novel risk factor based approach:the Euro Heart Survey on atrial fibrillation.Chest 2010;137:263-272.

65. Pisters R,Lane DA,Nieuwlaat R,de Vos CB,Crijns HJ,Lip GY.A novel userfriendly score (HAS-BLED) to assess 1-year risk of major bleeding in patients with atrial fibrillation: the Euro Heart Survey.Chest. 2010;138:1093-1100.

66. Wilson PW,D'Agostino R Sr,Bhatt DL,Eagle K,Pencina MJ,Smith SC,Alberts MJ,Dallongeville J, Goto S,Hirsch AT, Liau CS,Ohman EM,Röther J,Reid C,Mas 
JL,Steg PG;REACH Registry.An international model to predict recurrent cardiovascular disease.Am J Med.2012;125:695-703.e1.

67. Lip GY,Brechin CM,Lane DA.The global burden of atrial fibrillation and stroke: a systematic review of the epidemiology of atrial fibrillation in regions outside North America and Europe.Chest.2012;142:1489-98.

68. Nisen P,Rockhold F.Access to patient-level data from GlaxoSmithKline clinical trials. N Engl J Med.2013;369:475-8.

69. Goldacre B.Are clinical trial data shared sufficiently today?No.BMJ. 2013;347:f1880

70. Mallmann AB,Fuchs SC,Gus M,Fuchs FD,Moreira LB.Population-attributable risks for ischemic stroke in a community in South Brazil:a case-control study.PLoS One.2012; 7:e35680.

71. Healey JS,Connolly SJ,Gold MR, Israel CW,Van Gelder IC,Capucci A,Lau CP, Fain E,Yang S,Bailleul C,Morillo CA,Carlson M,Themeles E,Kaufman ES,Hohnloser SH;ASSERT Investigators. Subclinical atrial fibrillation and the risk of stroke.N Engl J Med.2012;366:120-9.

72. Loehr LR,Rosamond WD,Poole C,McNeill AM,Chang PP,Deswal A,Folsom AR, Heiss G.The potentially modifiable burden of incident heart failure due to obesity:the atherosclerosis risk in communities study.Am J Epidemiol.2010;172:781-9.

73. Ainsworth JD,Carruthers E,Couch P,Green N,O'Flaherty M,Sperrin M, Williams R,Asghar Z,Capewell S,Buchan IE.IMPACT:a generic tool for modelling and simulating public health policy.Methods Inf Med.2011;50:454-63.

74. Bowman S,Unwin N,Critchley J,Capewell S,Husseini A,Maziak W,Zaman S,Ben Romdhane H,Fouad F,Phillimore P,Unal B,Khatib R,Shoaibi A,Ahmad B.Use of evidence to support healthy public policy: a policy effectivenessfeasibility loop.Bull World Health Organ.2012;90:847-53.

75. Bruthans J,Cífková R,Lánská V,O'Flaherty M,Critchley JA,Holub J,Jansky $\mathrm{P}, Z$ várová J,Capewell S.Explaining the decline in coronary heart disease mortality in the Czech Republic between 1985 and 2007.Eur J Prev Cardiol. 2012 Nov 24.[Epub ahead of print]

76. Krijthe BP,Kunst A,Benjamin EJ,Lip GY,Franco OH,Hofman A,Witteman JC,Stricker $\mathrm{BH}$, Heeringa J.Projections on the number of individuals with atrial fibrillation in the European Union,from 2000 to 2060.Eur Heart J.2013;34:274651.

77. Kasmeridis C,Apostolakis S,Ehlers L,Rasmussen LH,Boriani G,Lip GY.Cost Effectiveness of Treatments for Stroke Prevention in Atrial Fibrillation:Focus on the Novel Oral Anticoagulants.Pharmacoeconomics.2013 Oct 2.[Epub ahead of print]

78. Ortegón M,Lim S,Chisholm D,Mendis S.Cost effectiveness of strategies to combat cardiovascular disease,diabetes, and tobacco use in sub-Saharan Africa and South East Asia: mathematical modelling study.BMJ.2012;344:e607.

79. Tengs T,Adams ME,Pliskin JS,Safran DG,Siegel JE,Weinstein MC,Graham JD.Five hundred life-saving interventions and their cost-effectiveness. Risk Anal.1995;15:369-390.

80. Weintraub WS,Cohen DJ.The limits of cost-effectiveness analysis.Circ Cardiovasc Qual Outcomes.2009;2:55-8. 
81. Wilkinson L. 2005.How to build scenarios.Planning for "long fuse, big bang" problems in an era of uncertainty. http://www.wired.com/wired/scenarios/build.html (checked 29/10/13)

82. Van der Heijden K.1997.Scenarios, Strategies and the Strategy Process. Centre for Organisational Learning and Change,Nijenrode University. http://www.library.nijenrode.nl/library/publications/nijrep/1997-01/1997-01.html (checked 29/10/13).

83. Ogilvy J. and Schwartz P 2004.Plotting your scenarios. An Introduction to the Art and Process of Scenario Planning. http://www.gbn.com/ArticleDisplayServlet.srv?aid=34550 (checked 29/10/13).

84. Forecast Techniques - Technology Futures, Inc. 2000. http://www.tfi.com/rescon/TF_Techniques.html (checked 29/10/13).

85. Miller G,Hughes-Cromwick $\bar{P}$, Roehrig C.National spending on cardiovascular disease, 1996-2008.J Am Coll Cardiol.2011;58:2017-9.

86. Luengo-Fernandez R, Leal J,Gray AM.UK research expenditure on dementia, heart disease, stroke and cancer: are levels of spending related to disease burden?Eur J Neurol.2012;19:149-54.

87. Castellucci LA,Cameron C,Le Gal G,Rodger MA,Coyle D,Wells PS,Clifford T,Gandara E,Wells G,Carrier M.Efficacy and safety outcomes of oral anticoagulants and antiplatelet drugs in the secondary prevention of venous thromboembolism:systematic review and network metaanalysis.BMJ.2013;347:f5133.

88. Grace C.(2005),"Update on China and India and access to medicines", briefing paper",DFID/HRSC, London,November, pp.1-42

89. Davies A,Bakhai A,Schmitt C,Barrett A,Graham-Clarke P,Sculpher M. Prasugrel vs clopidogrel in patients with acute coronary syndrome undergoing percutaneous coronary intervention:a model-based cost-effectiveness analysis for Germany, Sweden,the Netherlands,and Turkey.J Med Econ.2013;16:51021.

90. Fournier N,Toesca R,Bessereau J,Champenois A,Mazille A,Luigi S,Yvorra S,Paganelli F,Brun PM, Michelet P, Meyran D,Auffray JP,Bonello L.Ticagrelor or prasugrel for pre-hospital protocols in STEMI?Int J Cardiol.2013;168:4566-7.

91. Hogerzeil HV.Big Pharma and social responsibility--the Access to Medicine Index.N Engl J Med.2013;369:896-9. 